\title{
FURTHER CHARACTERIZATION OF AN INSULIN ANTAGONIST IN THE SERUM OF PATIENTS IN DIABETIC ACIDOSIS
}

\author{
By JAMES B. FIELD, FRANK TIETZE, AND DEWITT STETTEN, JR., WITH THE \\ TECH NICAL ASSISTANCE OF MINNIE L. WOODSON
}

\author{
(From the National Institute of Arthritis and Metabolic Diseases, National Institutes of Health, \\ Public Health Service, Bethesda, Md.)
}

(Submitted for publication July 1, 1957; accepted July 18, 1957)

We have previously described an insulin antagonist in the sera of patients in diabetic acidosis $(1,2)$. The protein nature of this material was suggested by its lability at $100^{\circ} \mathrm{C}$. and its electrophoretic migration with the $\alpha$-globulins. The antagonist was not a lipoprotein and did not exhibit any insulinase activity. Its inhibitory effect was still demonstrable whether it was added to the hemidiaphragm preparation before or after exposure to insulin. Experiments using insulin- $\mathrm{I}^{181}$ indicated that the antagonist did not compete with insulin for binding sites on diaphragm (2).

Further characterization of this insulin antagonist serves as the basis for this report.

\section{METHODS AND MATERIALS}

The method for determining the insulin effect was the same as was used previously and depends on the ability of insulin to augment glycogen deposition by the rat hemidiaphragm (1). In the presence of normal serum the insulin effect has been found to be 5.35 micromoles of glycogen (glucose equivalent) per gram of tissue (1).

Serum or plasma used in these experiments was obtained from patients in diabetic acidosis at the time of their admission to the hospital, before or shortly after insulin therapy was started. ${ }^{1}$ Samples were kept frozen for over one year without any evident loss of insulin antagonist activity.

Trypsin digestion of insulin antagonist serum was accomplished by the addition of $12 \mathrm{mg}$. of crystalline trypsin (Worthington Biochemical Corp.) to $6 \mathrm{ml}$. of serum followed by incubation at room temperature for four hours. Because of the large excess of trypsin present, the hemidiaphragm assay procedure was modified slightly to pre-

1 We are indebted to Dr. F. Bruce Peck, Jr., Eli Lilly and Company, Dr. James Craig, Western Reserve Medical School, Drs. James Pittman and John Binion, University of Alabama Medical School, Dr. Dorothy Macy, Jr., Philadelphia General Hospital, Drs. Richard Eberley and Kenneth Young, Jefferson Medical School, Dr. William Morgan, Massachusetts General Hospital, and Dr. James Moss, Georgetown University Medical School, for their helpful cooperation in obtaining sera from patients in diabetic acidosis. vent digestion of the insulin in the system. Each hemidiaphragm was added to $1 \mathrm{ml}$. of trypsin-digested serum and $1 \mathrm{ml}$. of $0.04 \mathrm{M}$ phosphate buffer, $\mathrm{pH} 6.8$, and the mixture was agitated for five minutes using a stream of oxygen. The hemidiaphragms were then removed from this mixture and washed twice with buffer. While one hemidiaphragm was exposed to 0.2 unit of insulin in $2 \mathrm{ml}$. of buffer for one minute, the other was put in buffer without insulin. Incubation was then carried out as usual.

Chymotrypsin digestion was achieved by adding $12 \mathrm{mg}$. of crystalline chymotrypsin (Worthington Biochemical Corp.) to $6 \mathrm{ml}$. of insulin antagonist serum and incubating at room temperature for seven hours. At the end of this time $0.008 \mathrm{ml}$. of pure diisopropyl fluorophosphate (DFP) was added and the incubation continued for another 30 minutes. The addition of DFP was necessary to prevent the inactivation of insulin by chymotrypsin during the subsequent assay.

Serum was separated into its various protein components by starch block electrophoresis according to the method of Kunkel and Slater (3).2 Potato starch previously washed with barbital buffer ( $\mathrm{pH} 8.6$ ) was used. The electrophoresis of serum was carried out for 18 hours at $4^{\circ} \mathrm{C}$., using 350 volts and 150 milliamperes. The starch block was then cut up into segments, each of which was washed with buffer and centrifuged. The clear supernatant solution was then decanted. The various protein components were identified by plotting the protein concentration of each tube against the tube number as shown in Figure 1 . The protein was determined according to the modified method of Folin (4). In addition, albumin, $\alpha_{2}$-globulins, and $\beta$-globulins were located on the starch block by their distinctive color bands -yellow, greenish red, and rust, respectively. The contents of the tubes were then pooled as indicated in Figure 1 to give the five different protein fractions tested. The amounts of $\alpha_{1}-$ globulins and other protein fractions in sera from patients in diabetic acidosis were measured by paper electrophoresis using the method of Jencks, Jetton, and Durrum (5). ${ }^{3}$ The dry paper strip patterns were evaluated by transmission densitometry.4 Each electro-

${ }^{2} \mathrm{We}$ are indebted to Dr. Edward C. Franklin of the Rockefeller Institute for Medical Research for doing the protein fractionation.

${ }^{3}$ Dr. John Fahey of the National Cancer Institute kindly carried out these determinations.

4 Analytrol, Spinco Division, Beckman Instruments, Inc., Belmont, California. 
phoretic run in a given cell included at least one strip which contained $0.008 \mathrm{ml}$. of a standard normal human serum.

Glucagon activity in vivo was measured in fed male rabbits weighing approximately $2 \mathrm{Kg}$. After a baseline for blood glucose concentration had been obtained, 0.1 $\mathrm{ml}$. of normal serum containing $0.05 \mathrm{mg}$. of glucagon was injected rapidly into an ear vein. Fifteen minutes later the blood glucose was again determined by the micromethod of Folin (6).

The human insulin employed in this study was prepared essentially according to the method of Romans, Scott, and Fisher (7) with modifications appropriate for the handling of smaller quantities of starting material. Three hundred grams of human pancreas, obtained at autopsy, were extracted first with acidified ethanol and then at $\mathrm{pH} 8$, according to the published procedure (7). After adjustment of the $\mathrm{pH}$ to 5.3 , the solution was rendered lipid-free by the method of Light and Simpson (8). The resultant precipitate was dissolved in $75 \mathrm{ml}$. of $0.05 \mathrm{~N}$ hydrochloric acid and sodium chloride was added to a concentration of 25 per cent $(w / v)$. The precipitate obtained upon centrifugation was dissolved in $25 \mathrm{ml}$. of $0.5 \mathrm{M}$ acetic acid and the $\mathrm{pH}$ of the solution adjusted to 5.9 with $0.5 \mathrm{M}$ ammonium hydroxide. The suspension was refrigerated overnight and the precipitate was collected by centrifugation and redissolved in $25 \mathrm{ml}$. of $0.5 \mathrm{M}$ acetic acid. Final precipitation of the hormone was effected as before by adjustment of the $\mathrm{pH}$ to 5.9 with $0.5 \mathrm{M}$ ammonium hydroxide. The precipitate was collected by centrifugation, dissolved in $25 \mathrm{ml}$. of $0.05 \mathrm{~N}$ hydrochloric acid and, after overnight dialysis against distilled water, was lyophilized, yielding $21 \mathrm{mg}$. of saltfree product. Concurrently, the supernatant fluids resulting from centrifugation of the ammonium acetate precipitates were combined and also dialyzed against water and lyophilized. The yield of this product was $72 \mathrm{mg}$. Examination of the preparations by paper chromatography (8) revealed, surprisingly, that while both products contained detectable amounts of insulin, that which had been recovered from the ammonium acetate supernatant fractions contained a higher proportion of the hormone. The latter preparation was kindly assayed through the cooperation of Dr. Otto $\mathrm{K}$. Behrens of the Lilly Research Laboratories, and found to possess an activity of 1.8 units per milligram. This material was employed in these studies without further purification.

Monkey growth hormone was a generous gift from Dr. C. H. Li, University of California. Glucagon was kindly supplied by Eli Lilly and Company.

\section{RESULTS}

Table I indicates that trypsin digestion does not alter the ability of serum from Case IX (2) to inhibit the insulin effect. Normal serum subjected to trypsin digestion did not produce any significant reduction of the insulin effect. Chymotrypsin digestion, however, did inactivate the in-
TABLE I

Failure of trypsin digestion to inactivale serum insulin antagonist

\begin{tabular}{cccc}
\hline \hline $\begin{array}{c}\text { Treatment of } \\
\text { serum }\end{array}$ & $\begin{array}{c}\text { Amount } \\
\text { of serum }\end{array}$ & $\begin{array}{c}\text { Insulin effect } \\
\text { (micromoles [glucose } \\
\text { equiv.] per gram } \\
\text { of tissue) }\end{array}$ & $\begin{array}{c}\text { No. of } \\
\text { determi- } \\
\text { nations }\end{array}$ \\
\hline $\begin{array}{c}\text { Trypsin digested } \\
\text { serum, Case IX }\end{array}$ & $m l$. & Mean \pm S.E.M. & \\
$\begin{array}{c}\text { Untreated serum, } \\
\text { Case IX }\end{array}$ & 1 & $-0.03 \pm 0.84$ & 3 \\
$\begin{array}{c}\text { Trypsin-digested } \\
\text { normal serum }\end{array}$ & 1 & $4.28 \pm 0.85$ & 12 \\
\hline
\end{tabular}

sulin antagonist in the serum from this same patient (Table II). Since DFP had been added to the serum after the chymotrypsin digestion it was important to determine its effect on the insulin antagonist. The findings indicate that DFP, by itself, does not inactivate the humoral insulin inhibitor.

In an earlier paper the insulin antagonist was reported to reside in the $\alpha$-globulin fraction of the serum proteins (2). At that time it could not be determined whether it was localized in the $\alpha_{1}$ or the $\alpha_{2}$ fraction. However, using starch block electrophoresis it was possible to obtain some separation of these two protein fractions. In confirmation of our previous results, no antagonist activity was demonstrable in the albumin or the $\gamma$-globulin fractions. It is apparent from Table III that the bulk of the insulin antagonist activity was in the $\alpha_{1}$-globulin fraction of the serum proteins. At a concentration equal to that of original

TABLE II

Inactivation of insulin antagonist by chymotrypsin digestion

\begin{tabular}{lccc}
\hline & & \multicolumn{3}{c}{$\begin{array}{c}\text { Insulin effect } \\
\text { (micromoles } \\
\text { [glucose equiv.] } \\
\text { glycogen per }\end{array}$} & $\begin{array}{c}\text { No. of } \\
\text { determi- } \\
\text { gram of tissue) }\end{array}$ & $\begin{array}{c}\text { Amotions } \\
\text { of serum }\end{array}$ \\
\hline $\begin{array}{c}\text { greatment of serum } \\
\text { Untreated serum, } \\
\text { Case IX }\end{array}$ & 1.00 & $1.40 \pm 0.43$ & 8 \\
$\begin{array}{c}\text { Chymotrypsin + DFP } \\
\text { serum, Case IX }\end{array}$ & 1.00 & $7.79 \pm 1.98$ & 3 \\
$\begin{array}{c}\text { Untreated serum, } \\
\text { Case VII }\end{array}$ & 0.05 & $1.03 \pm 1.32$ & 3 \\
$\begin{array}{c}\text { DFP + serum, } \\
\text { Case VII }\end{array}$ & 0.05 & $1.13 \pm 1.68$ & 3 \\
\hline
\end{tabular}




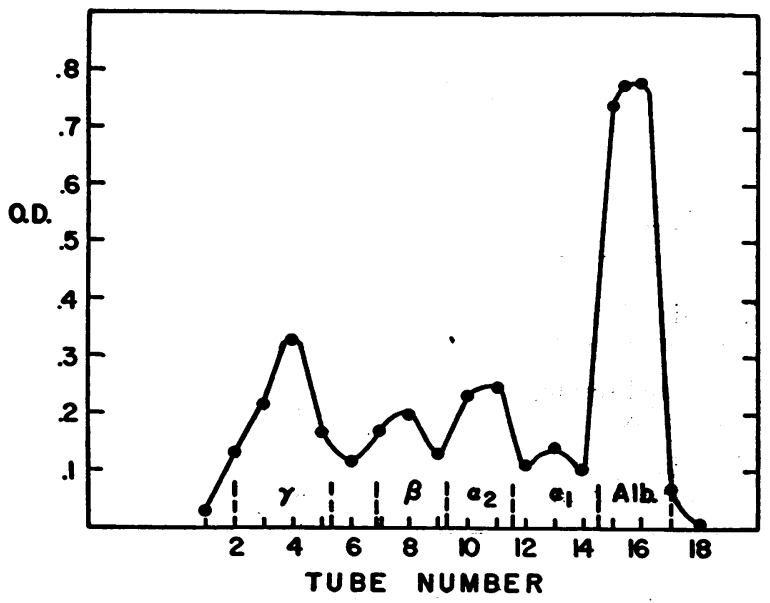

Fig. 1. Electrophoretic Separation of Components of Acidotic Serum

serum there was suggestive activity in the $\alpha_{2}$-globulins as compared to albumin, $\beta$ - and $\gamma$-globulins. The slight activity in the $\alpha_{2}$-globulin fraction was probably attributable to some contamination by $\alpha_{1}$ globulins since the separation of these two protein components obviously was not complete (Figure 1). The serum used for this experiment was the same which had been used for the previous protein fractionation (2). The earlier finding of some antagonist activity in $\beta$-globulins was undoubtedly due to less complete separation of serum proteins obtained in that experiment.

Since the insulin antagonist activity was contained in the $\alpha_{1}$-globulin fraction of the serum proteins, it seemed pertinent to determine whether the amount of this protein component was increased in sera exhibiting insulin antagonism. Scheurlen (9) has previously reported elevated levels of $\alpha_{1}$ - and $\alpha_{2}$-globulins in the sera of some diabetics during acidosis and infection. Table IV
TABLE III

Activity of various protein fractions of insulin antagonist serum

\begin{tabular}{|c|c|c|c|}
\hline Fraction & $\begin{array}{l}\text { Equivalent } \\
\text { amount } \\
\text { of whole } \\
\text { serum }\end{array}$ & $\begin{array}{c}\text { Insulin effect } \\
\text { (micromoles } \\
\text { [stucose equiv.] } \\
\text { per gram of } \\
\text { tissue) }\end{array}$ & $\begin{array}{c}\text { No. of } \\
\text { determi- } \\
\text { nations }\end{array}$ \\
\hline $\begin{array}{l}\text { Albumin } \\
\alpha_{1}-\text { globulins } \\
\text { arglobulins } \\
\beta \text {-globulins } \\
\gamma \text {-globulins }\end{array}$ & $\begin{array}{l}\text { ml. } \\
0.15 \\
0.15 \\
0.15 \\
0.15 \\
0.15\end{array}$ & $\begin{array}{c}\text { Mean } \pm \text { S.E.M. } \\
7.23 \pm 0.74 \\
1.41 \pm 0.99 \\
4.72 \pm 2.26 \\
8.52 \pm 1.77 \\
8.17 \pm 2.64\end{array}$ & $\begin{array}{l}3 \\
3 \\
3 \\
3 \\
3\end{array}$ \\
\hline
\end{tabular}

compares the distribution of the serum protein fractions in four cases of diabetic acidosis having insulin antagonist and six other patients in diabetic acidosis without such antagonist as measured by the present assay. Whereas considerable variations in the concentrations of protein fractions were encountered, in none of the four samples obtained from diabetics in ketosis which exhibited detectable antagonist did the values for $\alpha_{1}$-globulins fall outside the normal range. The failure to find increased $\alpha_{1}$-globulins is not necessarily inconsistent with the observation that the antagonist activity resides in that fraction. The $\alpha_{1}$-globulins are a heterogeneous group of proteins of which the insulin antagonist may be a minor component. Even a relatively large increase in the latter material might therefore not be evident from electrophoretic studies.

Since Snedecor, DeMeio, and Pincus (10) reported inhibition of the insulin effect on the rat hemidiaphragm by glucagon, the possibility existed that this substance was responsible for the insulin antagonism observed during diabetic acidosis. Table $\mathrm{V}$ indicates that the addition of as much as $0.1 \mathrm{mg}$. of glucagon to $1 \mathrm{ml}$. of normal

TABLE IV

Serum electrophoresis patterns in diabetic acidosis

\begin{tabular}{|c|c|c|c|c|c|c|c|}
\hline Serum & $\begin{array}{l}\text { Antagonist } \\
\text { present }\end{array}$ & $\begin{array}{l}\text { Total } \\
\text { protein }\end{array}$ & Albumin & $a_{1}$ & $\alpha_{2}$ & $\boldsymbol{\beta}$ & $\boldsymbol{\gamma}$ \\
\hline $\begin{array}{l}\text { Case I } \\
\text { Case III } \\
\text { Case VII } \\
\text { Case IX }\end{array}$ & $\begin{array}{l}+ \\
+ \\
+ \\
+\end{array}$ & $\begin{array}{c}\text { Gm. \% } \\
5.0 \\
8.1 \\
5.2 \\
7.0\end{array}$ & $\begin{array}{c}\text { Gm. \% } \\
1.63 \\
3.12 \\
2.15 \\
3.11\end{array}$ & $\begin{array}{c}\text { Gm. \% } \\
0.49 \\
0.34 \\
0.34 \\
0.35\end{array}$ & $\begin{array}{c}\text { Gm. \% } \\
0.90 \\
0.90 \\
0.71 \\
1.34\end{array}$ & $\begin{array}{c}\text { Gm. \% } \\
0.63 \\
1.93 \\
0.81 \\
1.27\end{array}$ & $\begin{array}{c}\text { Gm. \% } \\
1.36 \\
2.01 \\
1.18 \\
0.92\end{array}$ \\
\hline $\begin{array}{l}\text { Six other cases of } \\
\text { diabetic acidosis }\end{array}$ & - & $5.6-6.7$ & $1.34-3.18$ & $0.27-0.54$ & $0.56-1.26$ & $0.61-1.67$ & $0.96-2.35$ \\
\hline Normal & - & & $2.91-4.07$ & $0.24-0.50$ & $0.46-1.10$ & $0.38-1.18$ & $0.68-1.86$ \\
\hline
\end{tabular}


serum did not significantly lower the insulin effect. Further evidence that the antagonist is not glucagon is summarized in Table VI. When rabbits were injected intravenously with $0.1 \mathrm{ml}$. of normal serum containing $0.05 \mathrm{mg}$. of glucagon there was an average rise of $63 \mathrm{mg}$. per cent in their blood glucose levels within 15 minutes. An equal amount of normal serum or serum from Case VII did not produce any increase in the blood glucose. It had previously been shown that this amount of serum from Case VII was capable of inhibiting 0.2 unit of insulin (1).

Earlier it had been shown that sera obtained from acromegalic patients with diabetes did not inhibit the effect of 0.2 unit of insulin (2). Even though these patients demonstrated insulin resistance as measured by the intravenous insulin tolerance test using 0.1 unit per $\mathrm{Kg}$. of weight, it was possible that they did not at that time have very high levels of circulating growth hormone. The in vitro effect of monkey growth hormone on insulin action in the rat hemidiaphragm is shown in Table VII. This preparation of growth hormone had been shown to be metabolically active in humans (11). When used in a concentration of $160 \mu \mathrm{g}$. per ml. of normal serum, this growth hormone preparation did not antagonize insulin. In view of the finding of Vallance-Owen and Lukens (12) that the insulin antagonism observed in the depancreatized cat was dependent on both pituitary and adrenal hormones, the in vitro effects of both monkey growth hormone and hydrocortisone were evaluated in the hemidiaphragm test system. This combination did not exert any inhibition of the insulin effect (Table VII). Serum was obtained from a patient with hypopituitarism who had been given human growth hormone for the preceding three days. As a result of this administration, the patient developed some

TABLE V

Inability of glucagon to inhibit the insulin effect

\begin{tabular}{lccc}
\hline \hline Source of serum & $\begin{array}{c}\text { Insulin effect } \\
\text { (micromoles } \\
\text { [mlucose equiv.] } \\
\text { of serum } \\
\text { tissue) }\end{array}$ & $\begin{array}{c}\text { No. of } \\
\text { determi- } \\
\text { nations }\end{array}$ \\
\hline $\begin{array}{l}\text { Normal serum } \\
\text { Normal serum }+ \\
0.1 \mathrm{mg} \text {. glucagon }\end{array}$ & 1 & $5.35 \pm 0.48$ & 23 \\
\hline
\end{tabular}

TABLE VI

Absence of glucagon effect of insulin antagonist serum

\begin{tabular}{ccc}
\hline $\begin{array}{c}\text { Serum injected } \\
\text { into rabbit }\end{array}$ & Amount & $\begin{array}{c}\text { Blood sugar } \\
\text { change in } \\
15 \text { minutes }\end{array}$ \\
\hline $\begin{array}{c}\text { Normal serum and } \\
\mathbf{0 . 0 5} \text { mg. glucagon }\end{array}$ & $m b$. & ms. \% \\
Normal serum & 0.1 & 63 \\
$\begin{array}{c}\text { Insulin antagonist } \\
\text { serum, Case VII }\end{array}$ & 0.1 & -14 \\
\hline
\end{tabular}

evidence of insulin resistance as measured by the glucose-insulin tolerance tests (13). Nonetheless, serum obtained on the last day of growth hormone administration did not exhibit any insulin antagonism (Table VII). Although these observations make it unlikely that growth hormone is responsible for the insulin resistance during diabetic acidosis, this possibility is not completely ruled out. Growth hormone as obtained from the pituitary gland and used in vitro may not be the native hormone or produce all the metabolic effects usually ascribed to that hormone.

All the previously described experiments were performed using a commercially available mixture of beef and pork insulins. Although insulin antagonist activity had been found in the sera of patients in diabetic acidosis who had never had prior insulin therapy (1), it still seemed pertinent to ascertain the effect of this antagonist using human insulin in the assay system. Table VIII indicates that the insulin antagonist is just as effective against human insulin as against beef-pork insulin. It is thus conceivable that this insulin antagonist could be of importance in the etiology of some

TABLE VII

Failure of growth hormone to inhibit insulin effect

\begin{tabular}{|c|c|c|c|}
\hline Material tested & Amount & $\begin{array}{c}\text { Insulin effect } \\
\text { (micromoles } \\
\text { [glucose equiv.] } \\
\text { per gram of } \\
\text { tissue) }\end{array}$ & $\begin{array}{l}\text { No. of } \\
\text { determi- } \\
\text { nations }\end{array}$ \\
\hline $\begin{array}{l}\text { Monkey growth hormone, } \\
160 \mathrm{r} / \mathrm{ml} \text {. }\end{array}$ & $\begin{array}{c}m l . \\
1\end{array}$ & $\begin{array}{l}\text { Mean } \pm \text { S.E.M. } \\
6.49 \pm 1.60\end{array}$ & 3 \\
\hline$\left\{\begin{array}{l}\text { Monkey growth hormone, } \\
160 \mathrm{\gamma} / \mathrm{ml} \text {. } \\
\text { Hydrocortisone, } 4 \mathrm{r} / \mathrm{ml} .\end{array}\right.$ & 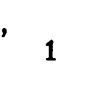 & $7.70 \pm 2.10$ & 3 \\
\hline $\begin{array}{l}\text { Serum from patient given } \\
\text { human growth hormone }\end{array}$ & 1 & $8.37 \pm 1.41$ & 3 \\
\hline
\end{tabular}


TABLE VIII

Inhibition of human insulin by insulin antagonist during diabetic acidosis

\begin{tabular}{cccc}
\hline \hline Serum & Type of insulin & $\begin{array}{c}\text { Insulin effect } \\
\text { (micromoles } \\
\text { [glucose equiv.] } \\
\text { glycogen per } \\
\text { gram of tissue) }\end{array}$ & $\begin{array}{c}\text { No. of } \\
\text { determi- } \\
\text { nations }\end{array}$ \\
\hline Diabetic acidosis & $\begin{array}{c}\text { Beef-pork, } \\
0.2 \text { unit/ml. }\end{array}$ & $\begin{array}{c}\text { Mean } \pm \text { S.E.M. } \\
1.32 \pm 2.02\end{array}$ & 3 \\
Diabetic acidosis & $\begin{array}{c}\text { Human, } \\
0.2 \text { unit } / \mathrm{ml} .\end{array}$ & $-0.30 \pm 1.58$ & 3 \\
Normal & $\begin{array}{c}\text { Human, } \\
0.2 \text { unit/ml. }\end{array}$ & $6.48 \pm 0.06$ & 3 \\
\hline
\end{tabular}

cases of human diabetes. This consideration derives support from the observation of VallanceOwen, Hurlock, and Please (14) that insulin added to plasma from diabetic patients requiring insulin and having a high blood sugar, but not in ketosis, did not increase the glucose utilization of the rat diaphragm. However, it is possible that during the process of preparation, the human insulin undergoes some modification which makes it less species specific than endogenous human insulin. Immunologically it has been shown that there is cross-reaction between antibodies prepared using beef insulin and human insulin (15).

\section{DISCUSSION}

It is still not possible to identify the exact nature or source of the insulin antagonist which can be detected in the sera of some patients in diabetic acidosis. The protein nature of the antagonist is indicated by its heat lability, electrophoretic migration, and the fact that it is non-dialyzable. Failure of trypsin digestion to inactivate the antagonist suggests that either arginine or lysine is not present in the molecule or is not in a position important to antagonist activity. Due to its broader specificity, chymotrypsin probably produces greater digestion of the substance with consequent loss of activity. It is still possible, though unlikely, that the active substance is a smaller molecule tightly bound to a protein and dependent on this combination for its activity.

Growth hormone, adrenal cortical steroids, and glucagon did not exhibit insulin antagonism in the rat hemidiaphragm system. Although these experiments tend to eliminate these substances as the cause of insulin antagonism, it is still possible that one or more of them, singly or in combination, may be related to the insulin antagonist in some way. This is suggested by the observations of VallanceOwen and Lukens (12) that depancreatized cats have a humoral insulin antagonist. The antagonist described by these workers was not present if the animal was adrenalectomized or hypophysectomized. The inhibitor could be restored by administering cortisone or hydrocortisone for four days. However, since a shorter period of adrenal steroid administration did not restore the antagonist, the in vitro addition of hydrocortisone and other materials to the diaphragm system might not be adequate to produce insulin antagonism. The question also arises as to whether the insulin antagonist reported by Vallance-Owen and Lukens (12) in the depancreatized cat is the same material which we have found in the sera of patients in diabetic acidosis. The factor in the cat is stable to freezing and thawing and is in the globulin fraction. The antagonist in diabetic acidosis is not a lipoprotein and is found in the $\alpha_{1}$-globulin fraction of the serum. Other chemical properties of the antagonist in the cat are not known. The antagonist in the cat was demonstrated using 1 milliunit of insulin per ml. of plasma, while in diabetic acidotic serum the antagonist was measured employing 200 milliunits of insulin per ml. of serum. Consequently, much smaller amounts could be detected in the cat serum. The use of much larger amounts of insulin in our test system could easily explain our failure to find insulin antagonist in all cases of diabetic acidosis examined. Only further experimental evidence will reveal whether these two factors are qualitatively similar.

\section{SUM MARY}

Further characterization of the insulin antagonist occurring in the sera of some patients in diabetic acidosis has been achieved. It was not inactivated by trypsin, but was destroyed by treatment with chymotrypsin. Upon starch block electrophoresis, it migrated with the $\alpha_{1}$-globulin fraction of the serum proteins. However, there did not seem to be any increase in the total amount of $\alpha_{1}$-globulins in the sera of four patients exhibiting insulin antagonist. Insulin antagonist serum did not exhibit any glucagon-like activity when in- 
jected intravenously into fed rabbits, nor did the addition of glucagon to normal serum produce insulin antagonism. The addition of large amounts of monkey growth hormone, by. itself and in 'com' bination with hydrocortisone, to normal serum did not inhibit the insulin effect on the rat hemidia phragm. Serum obtained from patient given human growth hormone in doses which caused some degree of insulin resistance was devoid of detectable insulin antagonist activity. The insulin antagonist was capable of inhibiting human insulin as well as beef-pork insulin in the diaphragm system.

Since the antagonist can oppose the action of human insulin it is suggested that it may be of etiologic significance in some cases of diabetes.

\section{REFERENCES}

1. Field, J. B., and Stetten, D., Jr., Humoral insulin antagonism associated with diabetic acidosis. Am. J. Med., 1956, 21, 339.

2. Field, J. B., and Stetten, D., Jr., Studies on humoral insulin antagonists in diabetic acidosis. Diabetes, 1956, 5, 391.

3. Kunkel, H. G., and Slater, R. J., Zone electrophoresis in a starch supporting medium. Proc. Soc. Exper. Biol. \& Med., 1952, 80, 42.

4. Lowry, O. H., Rosebrough, N. J., Farr, A. L., and Randall, R. J., Protein measurement with the
Folin phenol reagent. J. Biol. Chem., 1951, 193, 265 .

5. Jencks; W. P., Jetton, M: R., and Durrum, E. L., Paper electrophoresis as a quantitative method. Blochem. J., 1955, 60, 205.

6. Folin, 0 , The micro method for the determination of blood sugar. New England J. Med, 1932, 206, 722.

7. Romans, R. G., Scott, D. A., and Fisher, A. M., Preparation of crytalline insulin. Indust. \& Engin. Chem., 1940, 32, 908.

8. Light, A., and Simpson, M. V., Studies on the biosynthesis of insulin. I. The paper chromatographic isolation of $\mathrm{C}^{2}$-labeled insulin from calf pancreas slices. Biochim et biophys. acta, 1956, 20, 251.

9. Scheurlen, P. G., ther Serumeiweissveränderungen beim diabetes mellitus. Klin. Wchnschr., 1955, 33, 198.

10. Snedecor, J. G., DeMeio, R. H., and Pincus, I. J., Reduction by glucagon of glycogen deposition effect of insulin in rat diaphragm. Proc. Soc. Exper. Biol. \& Med., 1955, 89, 396.

11. Bergenstal, D. M., and Lubs, H., In preparation.

12. Vallance-Owen, J., and Lukens, F. D. W., Studies on insulin antagonism in plasma. Endocrinology, $1957,60,625$.

13. Lubs, H., and Bergenstal, D. M., In preparation.

14. Vallance-Owen, J., Hurlock, B., and Please, N. W., Plasma-insulin activity in diabetes mellitus. Lancet, 1955, 269, 583.

15. Arquilla, E. R., and Stavitsky, A. B., Evidence for the insulin-directed specificity of rabbit anti-insulin serum. J. Clin. Invest., 1956, 35, 467. 